\title{
SHORELINE ROTATION CAUSED BY LARGE-SCALE EXCAVATION OF REEF FLAT ON SANUR BEACH IN BALI
}

\author{
Masatoshi Endo ${ }^{1}$, Akio Kobayashi', Takaaki Uda ${ }^{2}$, Yasuhito Noshi ${ }^{3}$ and Susumu Onaka ${ }^{4}$ \\ In the southern part of Sanur Beach in Bali, beach erosion has occurred between groins after extensive beach \\ nourishment, resulting in shoreline rotation between the groins. The cause of shoreline changes was investigated by \\ field observations, including a bathymetric survey and the sampling of seabed materials, and numerical simulations \\ of beach changes were carried out using Noshi et al.'s model. It was concluded that the shoreline rotation was \\ triggered by the dredging of the reef flat, which caused a change in the wave direction on the reef flat due to the \\ diffraction of waves.
}

Keywords: coral reef; Bali; Sanur Beach; excavation of reefflat; shoreline change

\section{INTRODUCTION}

On Sanur Beach located in the southern part of Bali, as shown in Fig. 1, a wide coral reef has developed with sandy beaches composed of carbonate materials. This beach is a world-famous resort. Since the 1970s, beach erosion has become severe and the tropical coral reef environment has been lost because of the extensive coral mining to obtain materials for construction. To recover the sandy beach, a large-scale restoration project began in 2001. In this project, thirteen groins were built in combination with beach nourishment using approximately $3.0 \times 10^{5} \mathrm{~m}^{3}$ of sand $\left(d_{50}=0.6 \mathrm{~mm}\right)$ dredged from the seabed of a depth of 20-30 m offshore of the reef south of Nusa Dua Beach. After the beach nourishment, a stable sandy beach was formed along almost the entire length of Sanur Beach, but severe shoreline recession with the formation of a scarp occurred between groins G39 and GA2 located in the southern part of the beach (Fig. 2). An embayed shoreline was formed, causing the shoreline rotation and resulting in wave overtopping on the walkway along the shoreline during high tide. In this study, the cause of this shoreline rotation was investigated. For this purpose, the data obtained from monitoring surveys after beach nourishment had been completed were analyzed, and a further beach survey and sampling of the seabed materials were carried out on August 23, 2008. On the basis of these data sets, numerical simulations using the contour-line-change model proposed by Noshi et al. (2009), considering the equilibrium beach slope corresponding to each grain size and its composition, were carried out.

\section{GENERAL CONDITIONS OF STUDY AREA}

Sanur Beach is a coral reef coast with a length of $6.2 \mathrm{~km}$ and is located in the southeast part of Bali (Fig. 1). At Sanur Beach, the probability of the occurrence of calm waves with height less than $1 \mathrm{~m}$

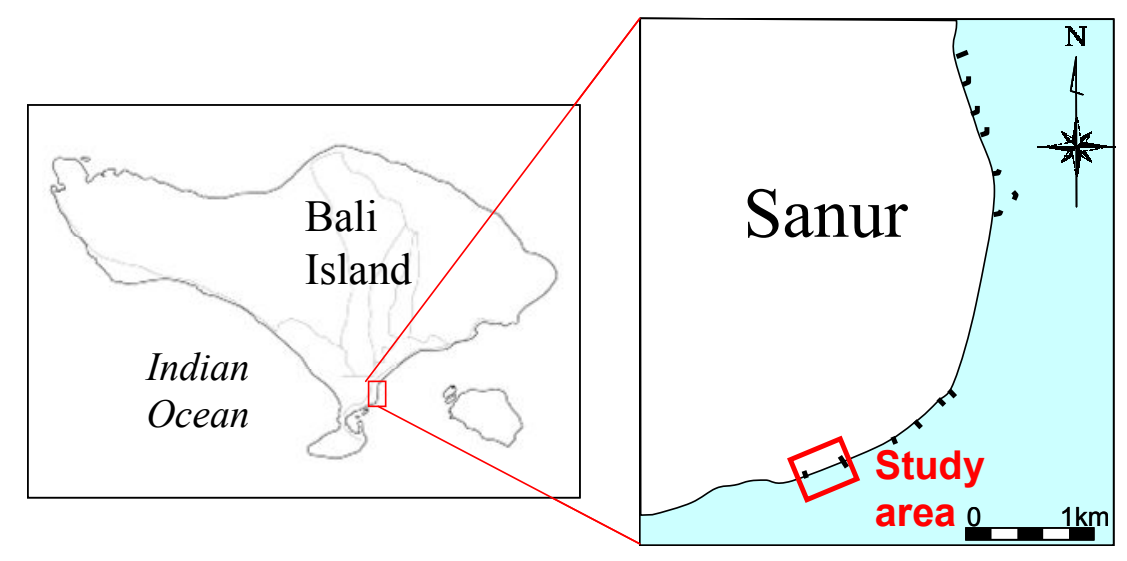

Figure 1. Location of Sanur Beach in Bali.

\footnotetext{
${ }^{1}$ Department of Oceanic Architecture \& Engineering, College of Science \& Technology, Nihon University, 7-24-1 Narashinodai, Funabashi, Chiba 274-8501, Japan

2 Public Works Research Center, 1-6-4 Taito, Taito, Tokyo 110-0016, Japan

3 Icom Net, Co., Ltd., 2-10-2 Nagata-cho, Chiyoda-ku, Tokyo 100-0014, Japan

${ }^{4}$ Nippon-koei Co., Ltd., 5-4 Kojimachi, Chiyoda-ku, Tokyo 102-8539 Japan
} 


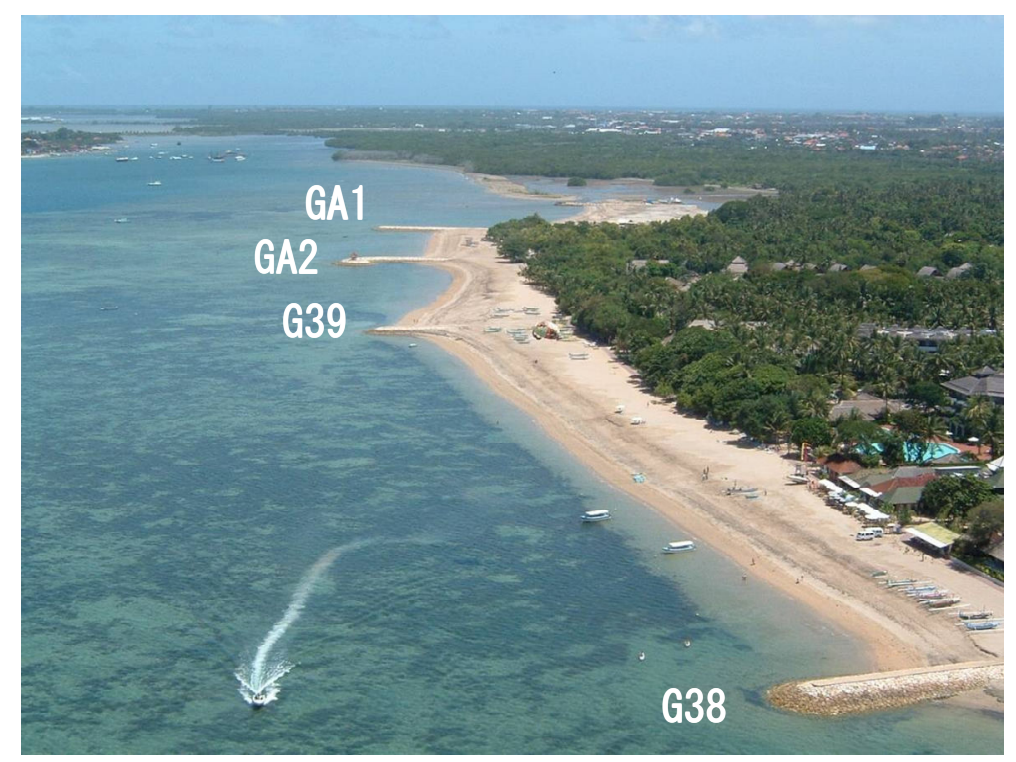

Figure 2. Aerial photograph of southern part of Sanur Beach (2004).

exceeds $95 \%$ most of the year, and the predominant wave period ranges between 9 and $11 \mathrm{~s}$ (Onaka et al., 2005) for deep-water waves. On Sanur Beach, thirteen groins and a detached breakwater were constructed, and beach nourishment was carried out using approximately $3.0 \times 10^{5} \mathrm{~m}^{3}$ of sand dredged from offshore of the reef on Nusa Dua Beach. To minimize the beach changes after beach nourishment, the shoreline configuration of the final beach was determined so that the shoreline was parallel with the shoreline before the nourishment, the direction of which was approximately normal to the predominant wave direction. The stable shoreline configuration was also predicted using the one-line model of beach changes. The beach width was determined to be $20 \mathrm{~m}$, taking into account the restoration of the shoreline to that in 1970 before the erosion.

The area focused in this study, is the rectangular zone in the southern part of Sanur Beach shown in Fig. 1. As shown in the oblique aerial photograph taken in 2004 (Fig. 2), four groins (GA1, GA2, G39 and G38) have been constructed to stabilize the nourished beach as part of the restoration work. The sandy beach was widened and the nourishment sand was deposited, forming a steep foreshore slope on the reef flat. The sandy beach (white part in Fig. 2) is clearly separated from the offshore reef flat covered with seaweed (black part in Fig. 2).

Note the shoreline configuration around the groins in Fig. 2; local shoreline recession can be seen between groins G39 and GA2, and the shoreline recession is severe east (downward in Fig. 2) of groin GA2, which differs from the shoreline in the adjacent area. The fact that the shoreline in the area between groins G39 and GA2 differs from the shoreline elsewhere along a long stretch of coastline shows that there are some special local factors causing this difference, and that the wave direction might have changed locally near this area because only the shoreline east of groin GA2 markedly receded.

As a key factor that might have affected the wave field around groins GA39 and GA2, the dredging of the reef flat carried out southwest of the present coast should be considered. Since 1997, large-scale excavation of the reef flat has been carried out to obtain the construction materials for land reclamation at a new resort island (Seino et al., 2006). Figure 3 shows the bathymetry of the coral reef after the dredging offshore of Sanur Beach, which was measured in March 2002. The reef flat, which developed uniformly in the longshore direction in the past, was excavated up to a depth of $9 \mathrm{~m}$ forming an embayment. This resulted in wave intrusion through the gap in the reef flat.

The change in the wave field due to this dredging has already been predicted by Osuga et al. (2004) using the parabolic equation (Isobe, 1987) given the bathymetry, waves with a significant wave height of $\mathrm{H}_{0}=1.3 \mathrm{~m}(\mathrm{~T}=13 \mathrm{~s})$, which is the predominant wave height at Sanur Beach, and the wave direction from the southeast. The area under study, where the shoreline rotation occurred, is demonstrated by a rectangular zone denoted by a solid line in Fig. 3. In this area, although waves were incident from the direction normal or counterclockwise relative to the shoreline before the dredging of the reef flat 


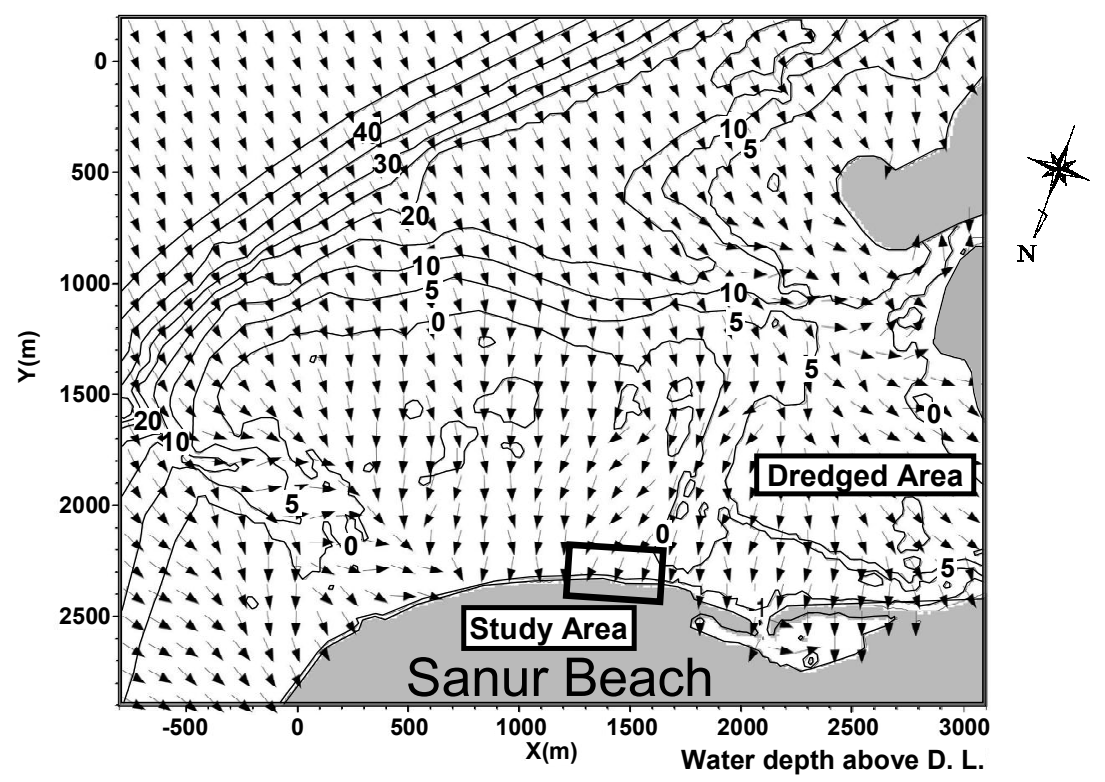

Figure 3. Bathymetry offshore of southern part of Sanur Beach and wave direction (Osuga et al., 2004).

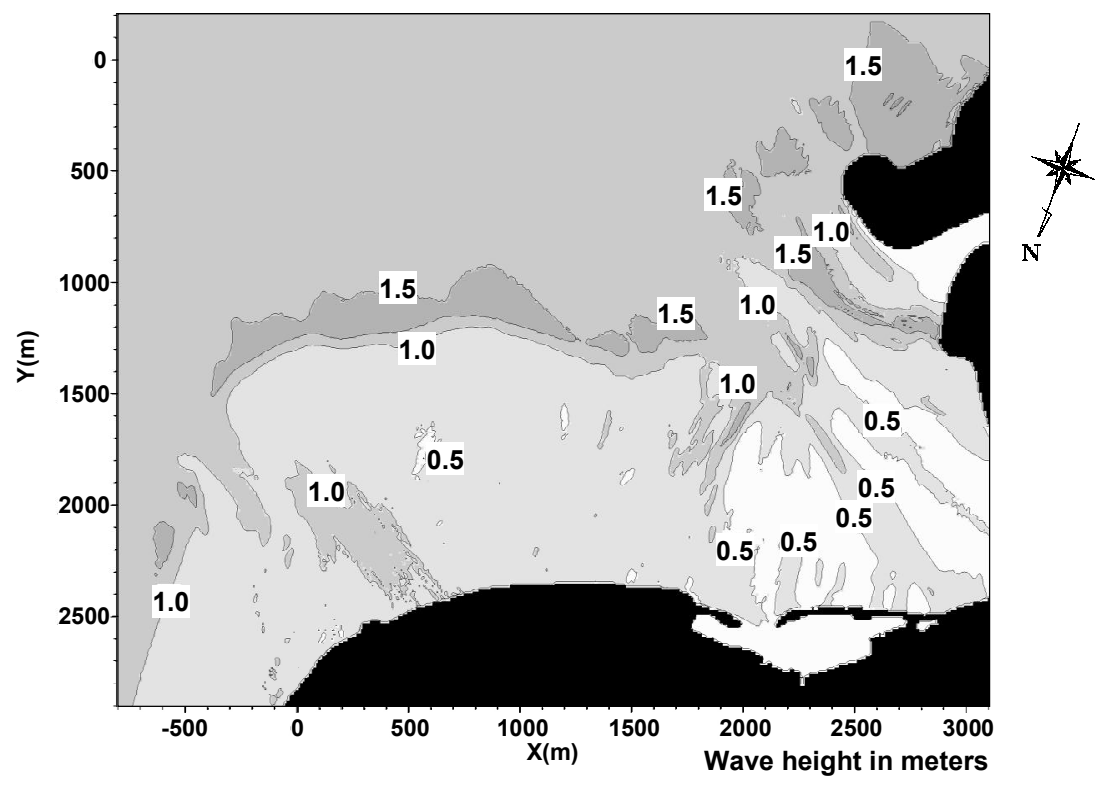

Figure 4. Wave height on reef (Osuga et al., 2004).

because of wave refraction along the reef edge, the diffracted waves was able to penetrate into this embayment after the excavation, resulting in an oblique wave incidence with a clockwise direction of $20^{\circ}$ relative to the shoreline. The change in wave direction is assumed to have caused the shoreline recession and advance in the western and eastern parts of the area under study, respectively, between groins G39 and GA2. Furthermore, the area where the wave direction changed is limited to within a 300 $\mathrm{m}$ stretch of the coast in the southern part of Sanur Beach. Regarding the distribution of wave height, rough waves can break on the coral reef, and the wave height on the coral is approximately $1 \mathrm{~m}$ because of the existence of a wide reef flat, as shown in Fig. 4. For the tide conditions of this beach, the high water level (H.W.L.) is $+2.6 \mathrm{~m}$ and the mean water depth over the reef flat is approximately $+0.5 \mathrm{~m}$ when the datum level (D.L.) is taken to be the low water level (L.W.L.). 
(a) Sep. 1997

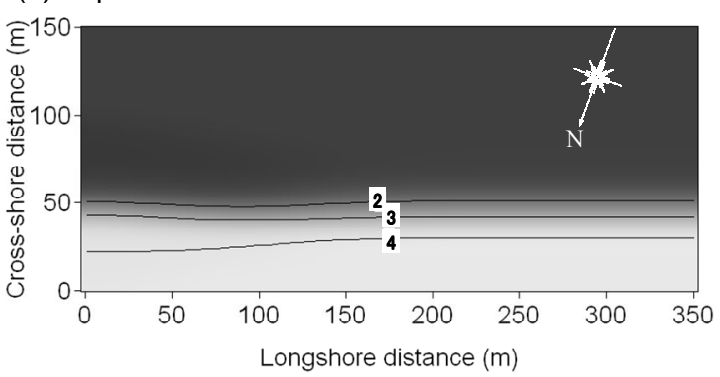

(c) Aug. 2004

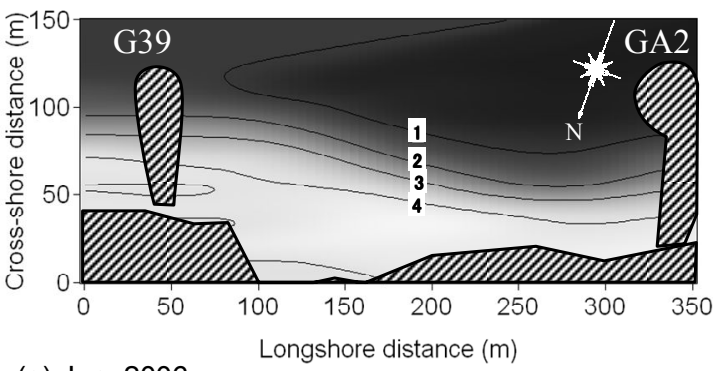

(e) Jun. 2006

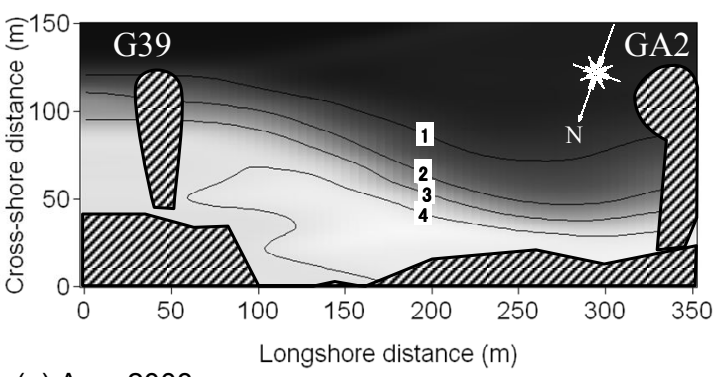

(g) Aug. 2008

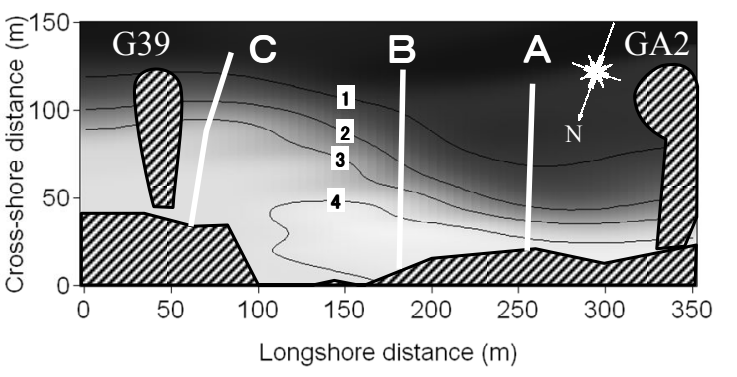

(b) Dec. 2003

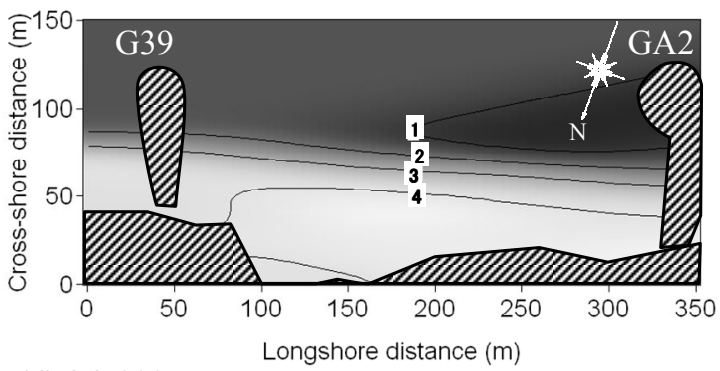

(d) Jul. 2005

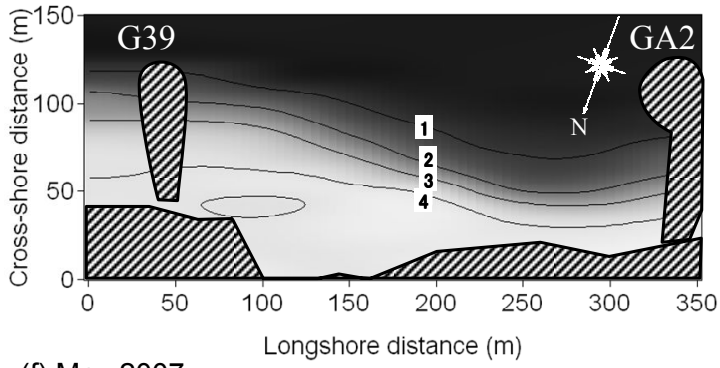

(f) May 2007

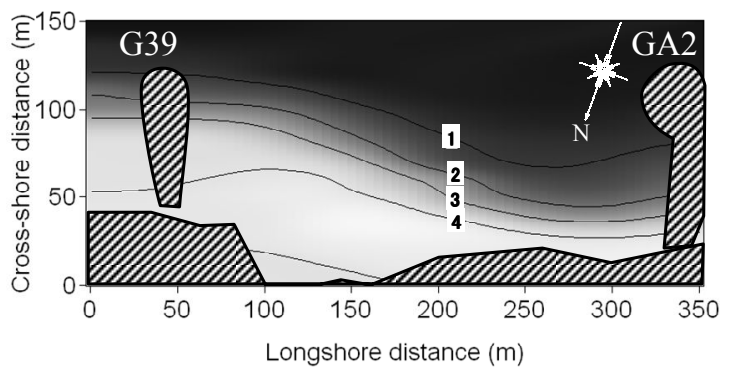

Figure 5. Topographic changes after beach nourishment.

\section{MONITORING OF BEACH CHANGES}

After the beach nourishment was completed in 2003, monitoring surveys were carried out at intervals of several months and the data obtained were analyzed. Figure 5 shows the beach topographies between groins G39 and GA2 in 1997 before the beach nourishment and in 2003 immediately after the nourishment, as well as the topographies measured by the monitoring surveys between 2004 and 2008 . In 1997, the beach was so narrow that the shoreline was located immediately offshore of the hinterland. As a result of beach nourishment, a 65-m-wide foreshore, which extends parallel with the mean coastline, had been produced by 2003. The shoreline of the nourished beach then started to rotate clockwise owing to wave action, and sand was deposited close to the tip of groin G39, permitting the leakage of a fraction of the sand around the tip of the groin until 2008. With these beach changes, the shoreline receded and a scarp was formed immediately east of groin GA2, resulting in the deterioration of the beach. 
Figure 6 shows the changes in longitudinal profiles between 2003 and 2008 along transects A, B and $\mathrm{C}$ located in the erosion, neutral and accretion zones, respectively, where the location of the transects is shown in Fig. 5. The mean sea level (M.S.L. $=$ D.L. $+1.3 \mathrm{~m}$ ) and the high water level $($ H.W.L. $=$ D.L. $+2.6 \mathrm{~m})$ are also indicated. Although a foreshore slope of 1/10 was formed owing to the beach nourishment, changes in the longitudinal profiles occurred in the elevation range between D.L. $+0.5 \mathrm{~m}$ and $+4.0 \mathrm{~m}$, and the profiles moved parallel with each other; erosion occurred along transect $\mathrm{A}$, resulting in shoreline recession by $23 \mathrm{~m}$, whereas the shoreline advanced by $24 \mathrm{~m}$ along transect $\mathrm{C}$. In contrast, the shoreline recession along transect B located midway between the groins, was as small as $5 \mathrm{~m}$, and a strong contrast was observed between the beach changes on the west and east sides of transect B. In each longitudinal profile, the ground elevation increased landward while maintaining a constant slope of $1 / 14$ between the mean shoreline position and D.L. $+4.0 \mathrm{~m}$, and a flat

\section{(a) Transect A}

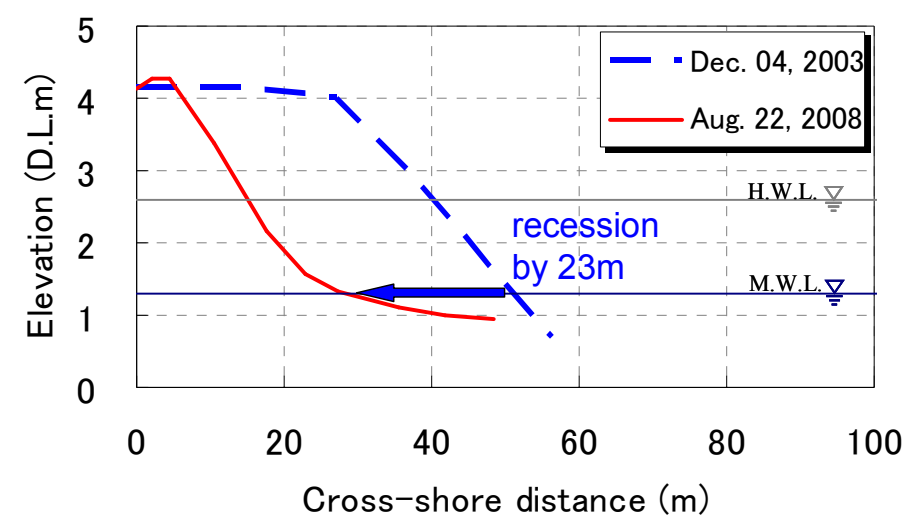

(b) Transect B

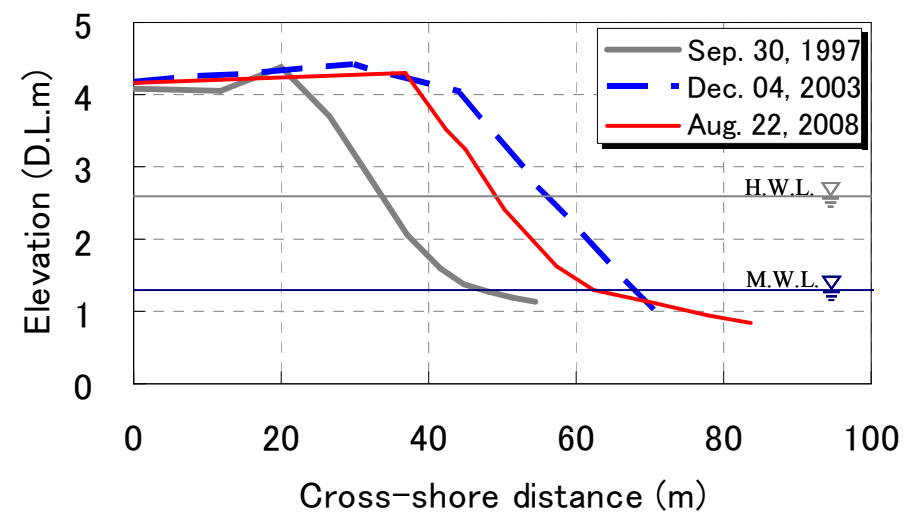

(c) Transect C

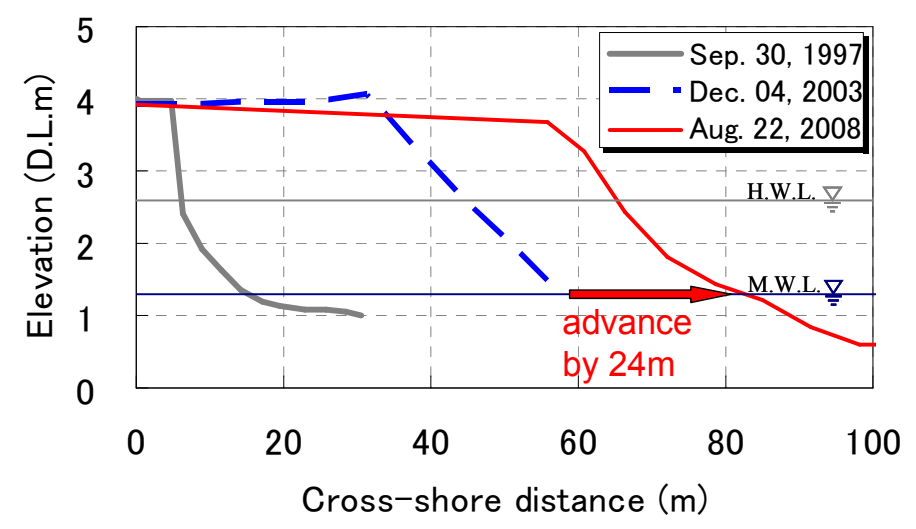

Figure 6. Profile changes along transects $\mathrm{A}, \mathrm{B}$ and $\mathrm{C}$. 
crown of the sandy beach extended landward.

Figure 7 shows the results of the sieve analysis of bed materials taken on August 23, 2008 along transects $\mathrm{A}, \mathrm{B}$ and $\mathrm{C}$. The content of gravel along transect $\mathrm{A}$ is as high as $18 \%$ at an elevation of $+1.9 \mathrm{~m}$, close to H.W.L., whereas the content of fine sand is only $7 \%$. The content of gravel and coarse sand is high between H.W.L. (D.L. $+2.6 \mathrm{~m}$ ) and M.W.L. (D.L. $+1.3 \mathrm{~m}$ ). Along transect B, similar results were obtained. The grain size composition along transect $\mathrm{C}$ is also similar to that along transect $\mathrm{B}$, but the content of gravel is still significant at the elevation of D.L. $+0.6 \mathrm{~m}$.

\section{(a) Transect A}

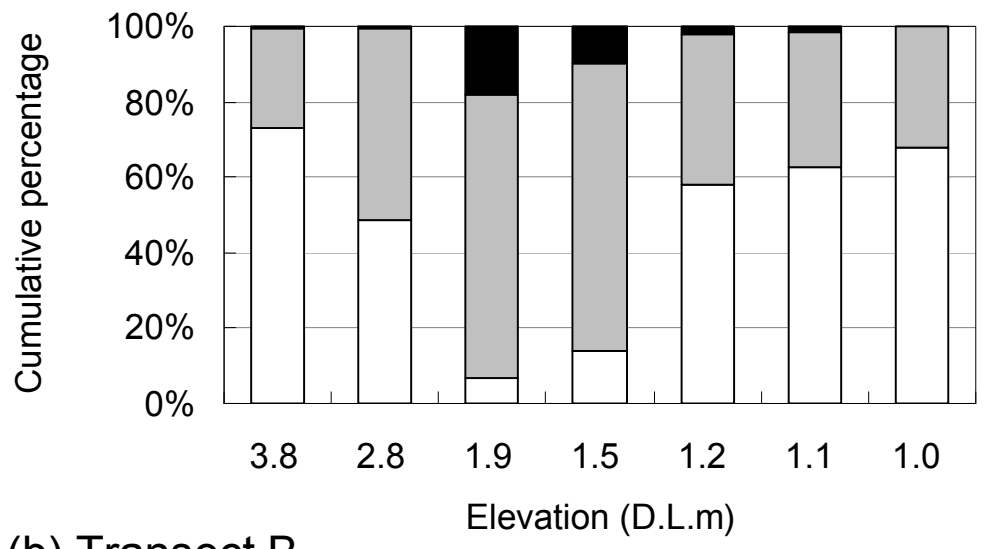

\section{(b) Transect B}

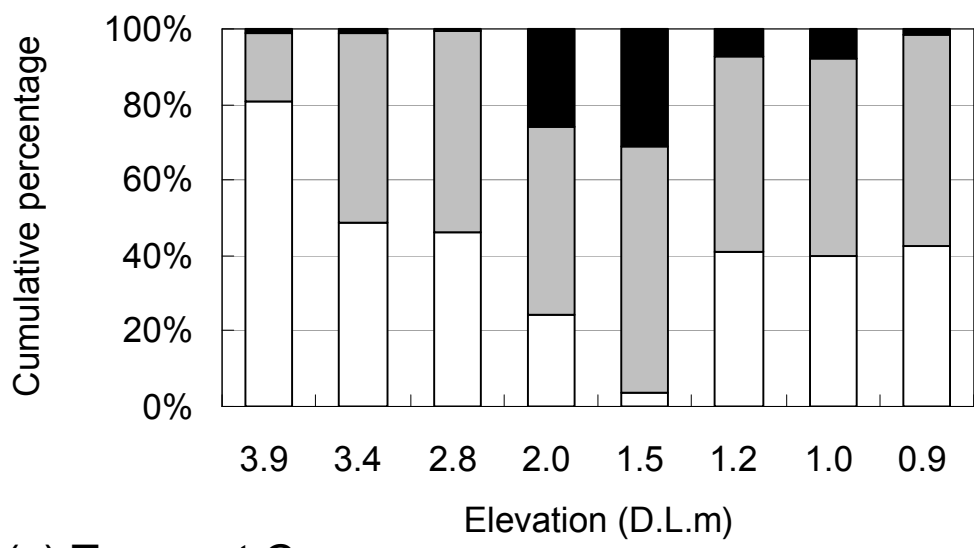

(c) Transect C

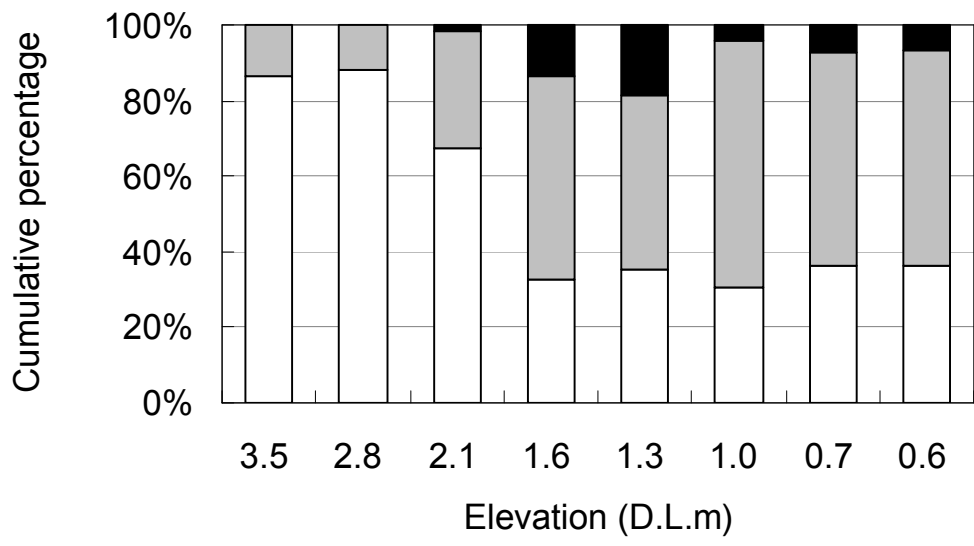

Gravel $(2 \mathrm{~mm}<\mathrm{d})$

$\square$ Medium sand $(0.425<\mathrm{d}<2 \mathrm{~mm})$

$\square$ Fine sand $(\mathrm{d}<0.425 \mathrm{~mm})$

Figure 7. Grain size composition along transects A, B and C. 
NUMERICAL MODEL

The contour-line-change model proposed by Noshi et al. (2009), considering the equilibrium beach slope corresponding to each grain size and its composition, was applied to analyze the beach changes on the basis of field data. In the model, to take each grain size $d^{(\mathrm{k})}$ into account, its contribution to the equilibrium slope $\tan \beta_{c}^{(\mathrm{k})}$ is weighted by its content $\mu^{(k)}$. The weighted mean $\tan \bar{\beta}_{c}$ of the equilibrium slope $\tan \beta_{c}^{(\mathrm{k})}$ corresponding to each grain size $d^{(\mathrm{k})}$ is assumed to be given by Eq. (1).

$$
\ln \left(\tan \bar{\beta}_{c}\right)=\sum_{k=1}^{N} \mu^{(\mathrm{k})} \ln \left(\tan \beta_{c}^{(\mathrm{k})}\right)
$$

For the cross-shore sand transport equation, not only the effect of the composition of each grain size but also the effect of its equilibrium slope $\tan \beta_{c}^{(\mathrm{k})}$ is included, as shown in Eq. (2).

$$
\begin{aligned}
& q_{z}^{(k)}=\mu^{(k)} \cdot \varepsilon_{z}(z) \cdot \gamma \cdot K_{1}^{(k)} \cdot\left(E C_{g}\right)_{b} \cos ^{2} \alpha_{b s} \sin \bar{\beta} . \\
& \left\{r \cdot\left(\cot \beta / \cot \bar{\beta}_{c}-1\right)+(1-r) \cdot\left(\cot \beta / \cot \beta_{c}^{(k)}-1\right)\right\} \\
& ; k=1,2, \ldots, N \quad 0 \leq r \leq 1
\end{aligned}
$$

Here, $z$ is the elevation of a contour line, $q_{z}^{(k)} ; k=1,2, \cdots, N$ is the cross-shore sand transport of each grain size at elevation $z, \mu^{(k)}$ is the content of each grain size in the exchange layer, $\varepsilon_{z}(z)$ is equivalent to the depth distribution of longshore sand transport $\varepsilon_{x}(z)$ (Serizawa et al., 2003) and $\gamma$ is the ratio of the coefficient of cross-shore sand transport to that of longshore sand transport. $\left(E C_{g}\right)_{b}$ is the energy flux at the wave breaking point, $\alpha_{b s}$ is the angle between the wave crest and the contour line at the breaking point, $\beta$ is the angle of the longitudinal slope and $\bar{\beta}$ is the initial slope angle. The weight $r$, which is an empirical constant, is assumed to be 0.5 in this study. Similarly, the longshore sand transport equation for each grain size is given by Eq. (3).

$$
\begin{aligned}
& q_{x}^{(k)}=\mu^{(k)} \cdot \varepsilon_{x}(z) \cdot K_{1}^{(k)} \cdot\left(E C_{g}\right)_{b} \cdot \\
& \left(\cos \alpha_{b s} \sin \alpha_{b s}-\xi \frac{1}{\tan \beta} \cdot \cos \alpha_{b s} \cdot \frac{\partial H_{b}}{\partial x}\right)
\end{aligned}
$$

Here, $q_{z}^{(k)}(k=1,2, \ldots, N)$ is the longshore sand transport per unit depth for each grain size, $\varepsilon_{x}(z)$ is the depth distribution of longshore sand transport, and $\xi$ is the constant given by $K_{2}{ }^{(k)} / K_{1}{ }^{(k)}$, which depends on the physical conditions of the beach, where $K_{2}{ }^{(k)}$ is a function of $K_{1}{ }^{(k)}$ and is equivalent to the coefficient of Ozasa and Brampton (1980). $\tan \beta$ is the beach slope in the surf zone and $H_{\mathrm{b}}$ is the breaker height. The beach changes are predicted by simultaneously solving the longshore and crossshore sand transport equations and the continuity equation.

\begin{tabular}{|l|l|}
\hline \multicolumn{2}{|c|}{ Table 1. Calculation conditions. } \\
\hline Initial bathymetry & Bathymetry measured immediately after nourishment \\
Initial grain size and content & $0.106 \mathrm{~mm}(5 \%), 0.25 \mathrm{~mm}(45 \%), 0.425 \mathrm{~mm}(35 \%)$, \\
Width of exchange layer & $0.85 \mathrm{~mm}(10 \%), 2 \mathrm{~mm}(5 \%)$ \\
Wave conditions & $1.3 \mathrm{~m}$ \\
& Breaker height $\mathrm{H}_{\mathrm{b}}=1.0 \mathrm{~m}$ \\
Tide conditions & Breaker angle $\mathrm{a}_{\mathrm{b}}=20^{\circ}$ \\
Depth of closure, $\mathrm{h}_{\mathrm{c}}$ & M.S.L. $=\mathrm{D} . \mathrm{L} .+1.3 \mathrm{~m}$ \\
Berm height, $\mathrm{h}_{\mathrm{R}}$ & D.L. $+1.0 \mathrm{~m}$ \\
Boundary conditions & D.L. $+4.0 \mathrm{~m}$ \\
Coefficient of sand transport & Zero inflow and outflow across boundary \\
Coefficient of Ozasa and Brampton & $\mathrm{A}=0.3$ \\
(1980) & 0.5 \\
Ratio between longshore and & $\mathrm{K}_{\mathrm{z}} / \mathrm{K}_{\mathrm{x}}=0.2$ \\
cross-shore sand transport & $1 / 2$ on land and $1 / 3$ on seabed \\
Critical slope on land and seabed & $\Delta \mathrm{Y}=5 \mathrm{~m}$ and $\Delta \mathrm{z}=0.5 \mathrm{~m}$ \\
Mesh size & $\Delta \mathrm{t}=0.001$ \\
Time step & 500,000 \\
Total time steps &
\end{tabular}




\section{CALCULATION CONDITIONS}

On the basis of the predicted wave direction shown in Fig. 3, waves with a significant wave height of $1 \mathrm{~m}$ and a wave period of $13 \mathrm{~s}$ were assumed to be obliquely incident at an angle of $20^{\circ}$ clockwise relative to the normal to the shoreline of the nourished beach along with a tide condition of M.W.L. (D.L. $+1.3 \mathrm{~m}$ ) in 2003. The topographic changes and the change in the grain size of the seabed materials were numerically predicted. The initial grain size was determined from the beach materials obtained from the scarp formed by the shoreline recession, and a uniform distribution was assumed in the crossshore direction. Table 1 shows the calculation conditions including each initial grain size, its content and its corresponding equilibrium slope. The depth range of the calculation is from the depth of closure $h_{\mathrm{c}}$ of D.L. $+1.0 \mathrm{~m}$, i.e., the depth of the reef flat, to the berm height $h_{\mathrm{R}}$ of D.L. $+4 \mathrm{~m}$.

Figure 8 shows the predicted beach topography in 2008. The predicted and measured topographies shown in Figs. 8 and 5(g), respectively, are in good agreement. In the vicinity of the downcoast groin G39, the contour lines in the shallow water zone markedly advanced, implying that part of the sand might have been transported downcoast after turning around the tip of the groin. Figure 9 shows the measured and predicted shoreline changes. Although there are some differences, for example, the curvature of the predicted shoreline is less than that of the measured shoreline, the overall shoreline changes are in good agreement.

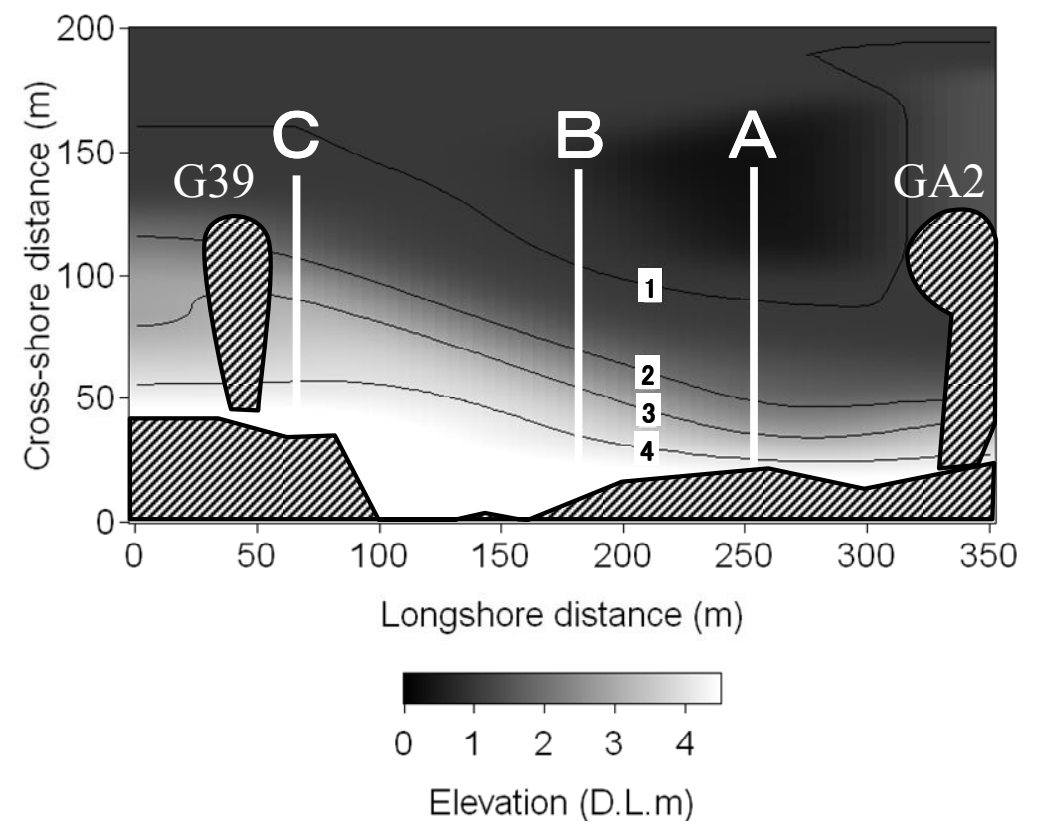

Figure 8. Predicted bathymetry.

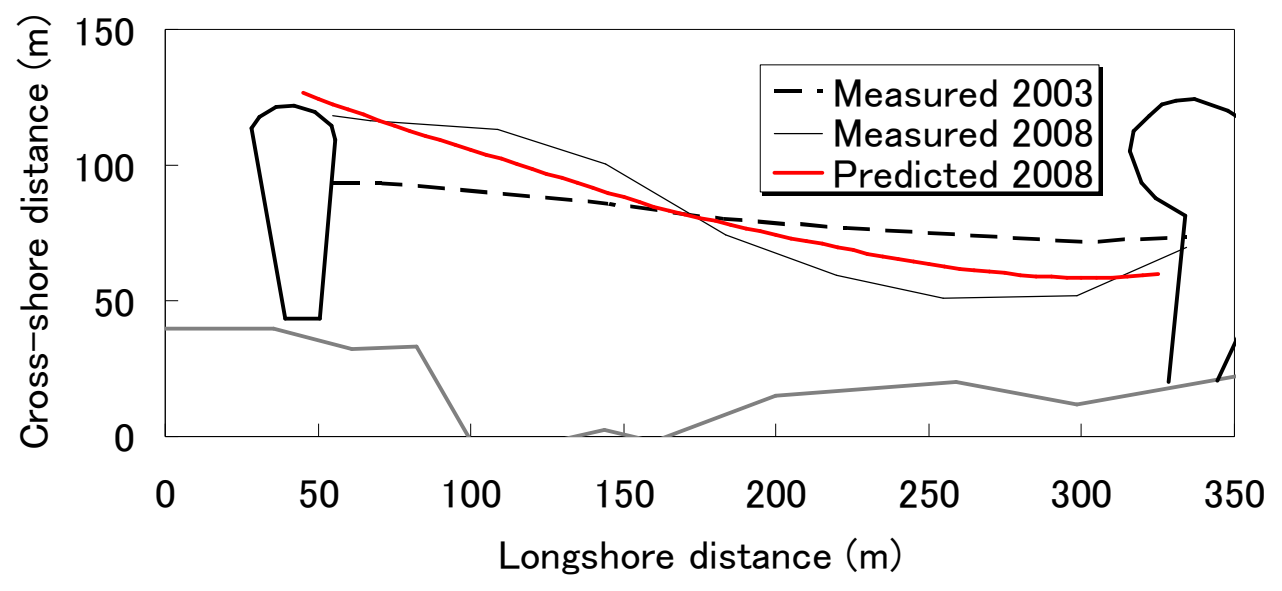

Figure 9. Measured and predicted shoreline changes. 
Figure 10 shows the predicted and measured longitudinal profiles. The profiles in the erosion and accretion zones are also in good agreement. Figure 11 shows the cross-shore distribution of the composition along transects A, B and C. Along transect A, the content of gravel is as high as $51 \%$ at $\mathrm{z}=+2.2$. $\mathrm{m}$, close to H.W.L., whereas the content of fine sand is only $3 \%$. Furthermore, the content of gravel and coarse sand is high between H.W.L. and M.W.L. These results are in good agreement with the cross-shore distribution of the grain size composition measured along transect A, as shown in Fig. 7. On the other hand, along transects B and C, a gravel content of as high as $70 \%$ was predicted between elevations $+2.2 \mathrm{~m}$ and $+2.7 \mathrm{~m}$, where the scarp was formed, but gravel did not appear in this zone in the measured distribution, as shown in Fig. 7, and instead the content of gravel is relatively high between L.W.L. and H.W.L. In this regard, the discrepancies between the measured and predicted distributions are significant.

\section{(a) Transect A}
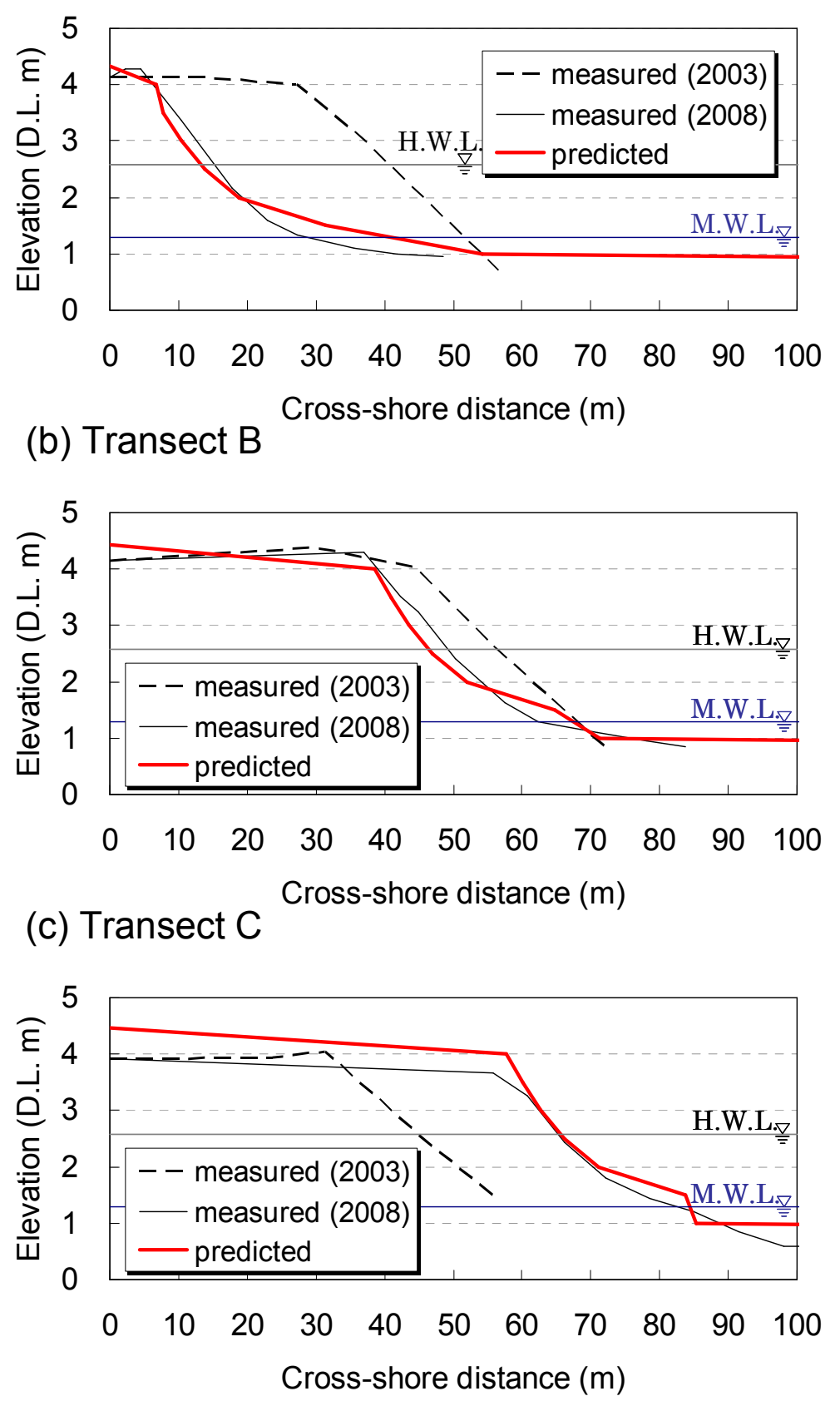

Figure 10. Predicted profile changes. 
(a) Transect A

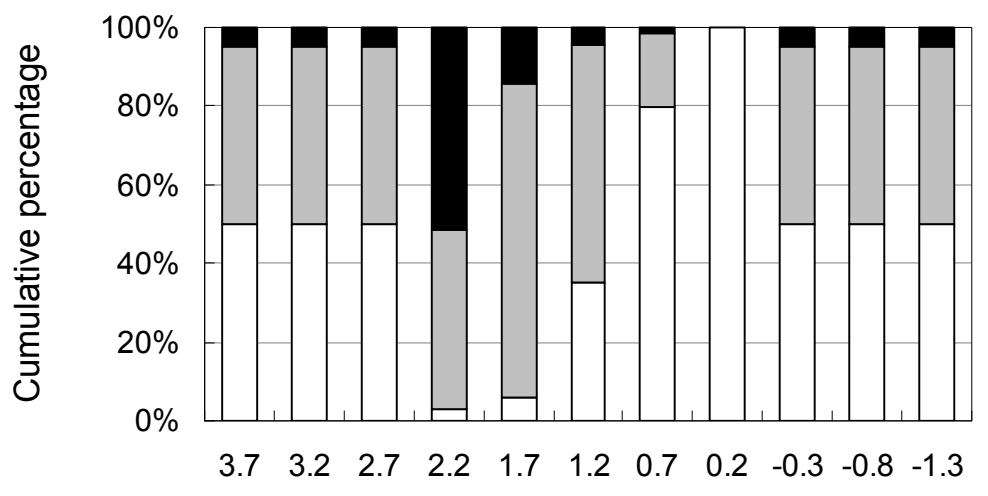

(b) Transect B

Elevation (D.L.m)

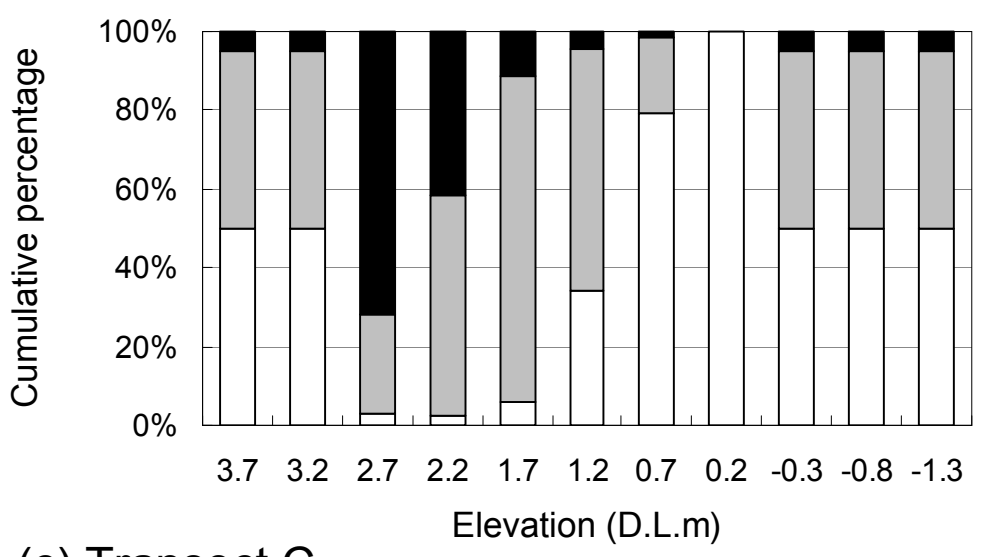

(c) Transect C

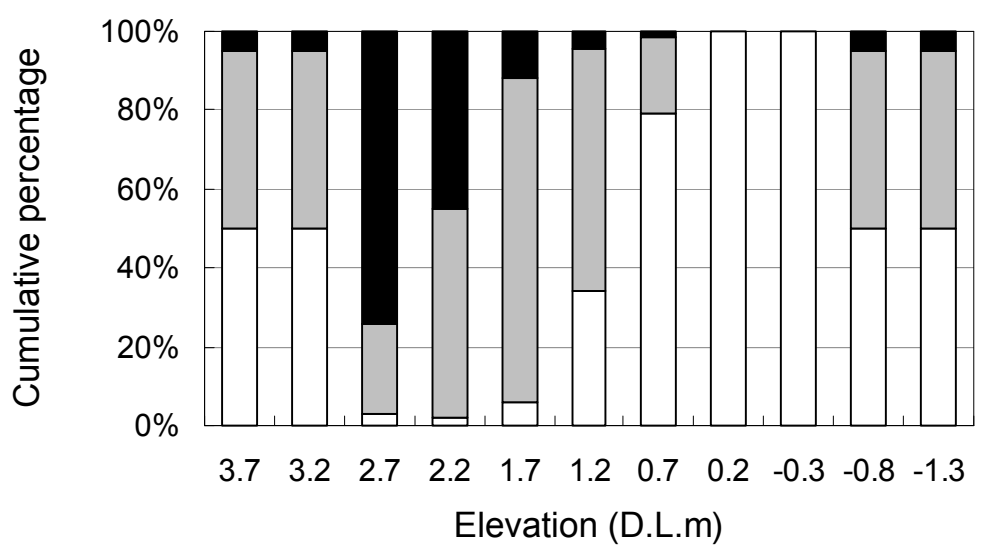

Gravel $(2 \mathrm{~mm}<\mathrm{d})$

$\square$ Medium sand $(0.425<\mathrm{d}<2 \mathrm{~mm})$

$\square$ Fine sand $(\mathrm{d}<0.425 \mathrm{~mm})$

Figure 11. Predicted grain size composition.

In the measured distribution of grain size along transect $\mathrm{C}$ located near groin $\mathrm{G} 39$, as shown in Fig. 7, gravel was observed at the reef bed with the bottom elevation of 0.7 and $0.6 \mathrm{~m}$ and the content ofcoarse sand was as high as $57 \%$, whereas the seabed material in this zone is fine sand according to the calculation results. Thus, the measured and calculation results are not necessarily in agreement. 
Figure 12 shows the beach condition at the tip of groin G39 on August 23, 2008. This figure clearly shows that coarser material has been transported downcoast from the west side of the groin after turning around the tip of the groin. Figure 13 shows the distribution of the median diameter of bed materials determined from the sampling of bed materials at 24 points around the tip of the groin. A slender band where coarse sand with a grain size of $0.45 \mathrm{~mm}$ is mainly deposited is formed from the right (west) side toward the tip of the groin, as shown by the broken line in Fig. 13, implying that part of the coarse sand was transported around the tip of the groin. Thus, the changes in the longitudinal profile in the study area were successfully predicted using the present model, but for the prediction of grain size distribution there still remain some problems to be solved. One of the reasons for this is that the accuracy of reproduction calculation was not particularly high; although the effect of tidal changes was significant on this coast because of the large tidal range of $2.6 \mathrm{~m}$, this effect was insufficiently taken into account in the present model by considering the mean sea level.

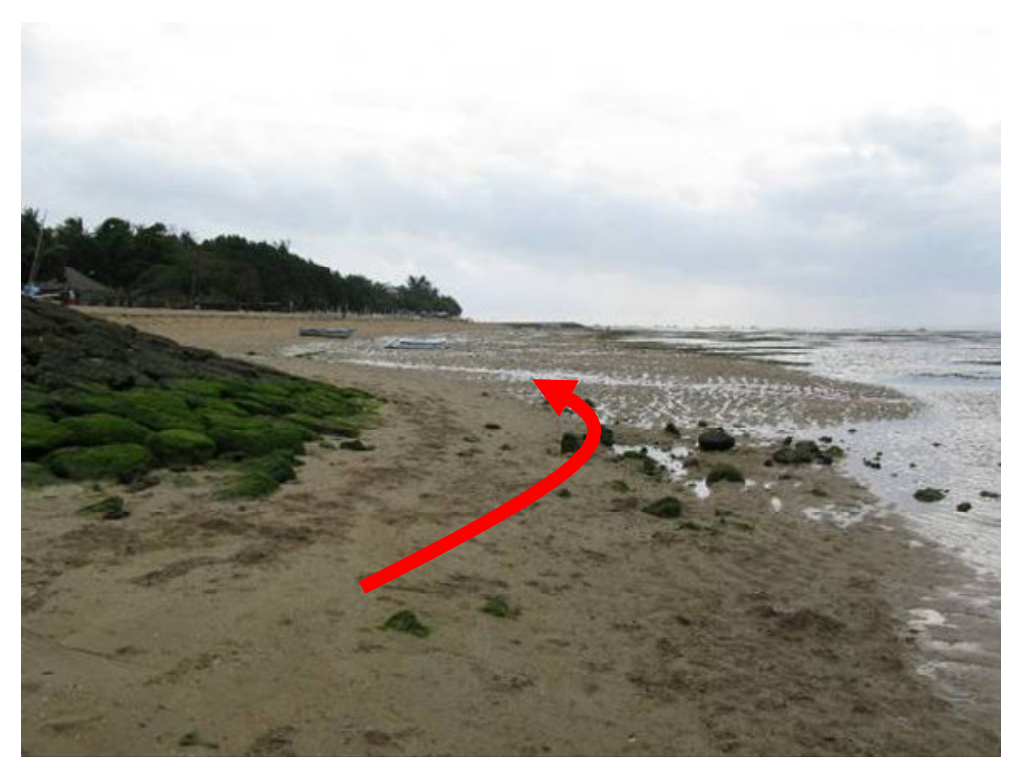

Figure 12. Sand deposition at tip of groin G39.

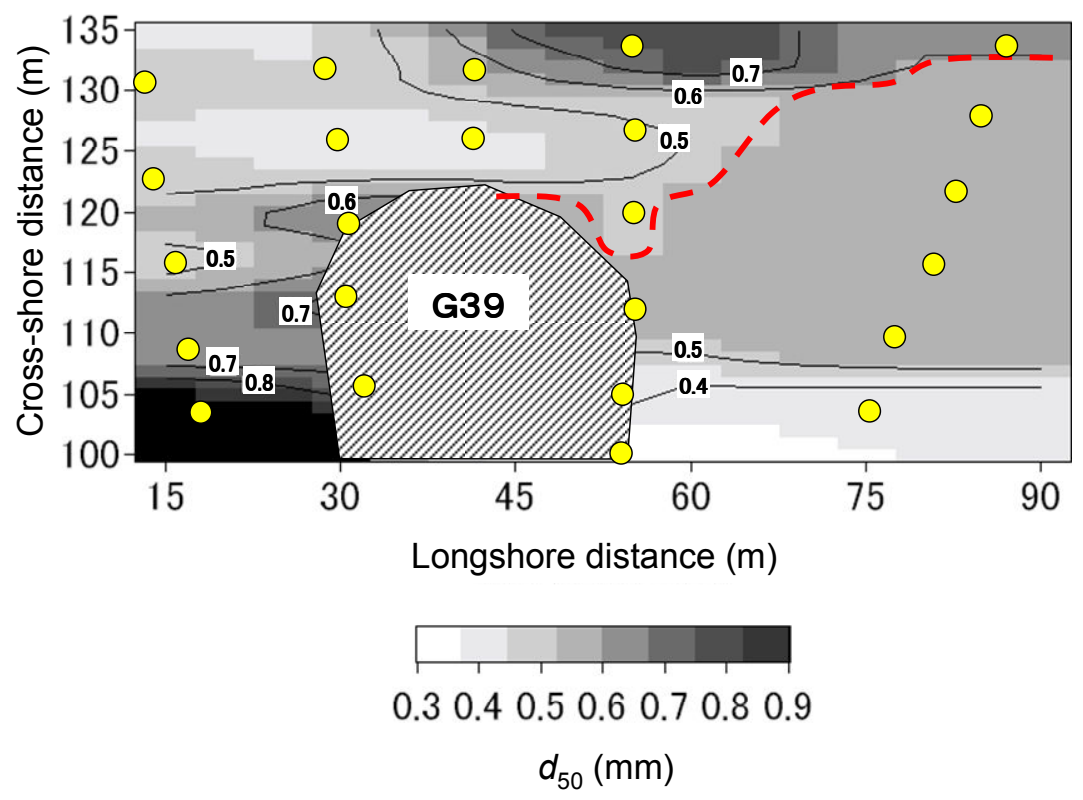

Figure 13. Distribution of $d_{50}$ around groin G39. 


\section{CONCLUSIONS}

The shoreline rotation between the groins on Sanur Beach in Bali was observed after nourishment. The beach changes were reproduced using the contour-line-change model considering grain size changes proposed by Noshi et al. (2009) given the bathymetry and the predicted wave conditions. It was found that the local shoreline rotation was triggered by an anthropogenic factor, i.e., the dredging of the reef flat, and the change in wave direction due to the formation of a deep embayment on the reef flat was the direct cause of the shoreline rotation. The measured and predicted profile changes were in good agreement. The accuracy of the predicted grain size distribution, however, was insufficient. The large tidal range of this coast is considered to be one of the reasons for this, and further studies are required on the prediction of grain size distribution.

\section{REFERENCES}

Isobe, M. 1987. A parabolic equation model for transformation of irregular waves due to refraction, diffraction and breaking, Coastal Eng. Japan, Vol. 30, No. 1, 33-47.

Noshi, Y., A. Kobayashi and T. Uda. 2009. Model for predicting bathymetric and grain size changes considering equilibrium beach slopes corresponding to composition of grain size and each grain size, J. Coastal Res., SI 56, Portugal, 108-112.

Onaka, S., S. Endo, T. Uda and I. Yoshii. 2005. Design of beach nourishment and beach response after nourishment on a reef coast, Annual Jour. Civil Eng. in the Ocean, Vol. 21, 475-480. (in Japanese)

Osuga, Y., T. Uda, S. Onaka, S. Endo, M. Serizawa and T. San-nami. 2004. Rapid formation of a barrier island and beach erosion caused by large-scale excavation of reef flat on carbonate beach, Proc. $29^{\text {th }}$ ICCE, 2074-2086.

Ozasa, H. and A. H. Brampton. 1980. Model for predicting the shoreline evolution of beaches backed by seawalls, Coastal Eng., Vol. 4, 47-64.

Seino, S., T. Uda, S. Onaka, M. Serizawa and T. San-nami. 2006. Large-scale excavation and land reclamation on reef flat and coral mining on Turtle Island in Bali, Indonesia, Proc. $10^{\text {th }}$ Inter. Coral Reef Symp., 876-881.

Serizawa, M., T. Uda, T. San-nami, K. Furuike and T. Kumada. 2003. Improvement of contour line change model in terms of stabilization mechanism of longitudinal profile, Coastal Sediments '03, $1-15$. 